\title{
Twice-Exceptionality in Australia: Prevalence Estimates
}

\author{
Michelle Ronksley-Pavia \\ Griffith University
}

\begin{abstract}
There is a considerable gap in empirical research on the prevalence rates of twice-exceptional students in Australian schools. Governments expect statistics when developing education policy and implementing funding support, so it is therefore imperative, as far as practicable, to quantify the number of twice-exceptional learners in Australia. Within the international literature, a number of different estimates exist of the prevalence of twice-exceptional students. However, the challenges of identifying two (or more) exceptionalities means that the exact prevalence rates of these learners remains unknown. Current research in this area is limited. Given the prevailing notions of giftedness and disability, this article explores the viability of convincingly estimating the number of twice-exceptional students in Australia. Knowledge of this prevalence is important to garner support and funding for these learners across schooling sectors.
\end{abstract}

\section{Introduction}

There is a scarcity of Australian empirical research studies on twice-exceptionality (Haines, Cornish, \& Bannister-Tyrrell, 2020; RonksleyPavia, Grootenboer, \& Pendergast, 2019; Wormald \& Vialle, 2011). Of those studies that have been published, there is limited examination of the prevalence of twiceexceptional children within our schools. The majority of twice-exceptional literature tends to focus on classroom provisions and teacher knowledge of this diverse population of students, without clear information on how many students need to be supported.

Relatedly, the identification of twiceexceptional students has largely been ignored in Australia. This is possibly due to the inherent difficulties with distinct definitions of the terms gifted and disability (Ronksley-Pavia, 2015), which may furthermore be confounded when the two apparently paradoxical terms are combined in a single individual. Notionally, the rationale for estimating prevalence rates is to inform advocacy, policy, interventions, and funding for these students within schools and communities.
At present, there are neither mandated collections of data on the number of Australian children who are identified as gifted, nor any statistics on the number of students identified as twice-exceptional. Nevertheless, mandated data collection exists for children with disability. Specifically, from 2015, all Australian schools have been required to participate in the annual Nationally Consistent Collection of Data on School Students with Disability (NCCD; 2020a). Information from the NCCD may potentially be useful in arriving at prevalence estimates for the number of twice-exceptional students in Australian schools.

\section{Giftedness and Twice-Exceptionality}

In Australia, the generally accepted model for defining giftedness is Gagné's (2013)

Differentiated Model of Giftedness and Talent, which defines giftedness as the possession of outstanding natural abilities in at least one ability domain, to a degree that places an individual at least among the top 10\% of age peers. Conversely, Gagné defines talent as outstanding mastery of systematically developed abilities in at least one field of human activity, to a degree that places an individual at least among the top $10 \%$ of age peers.

In comparison, definitions of twiceexceptionality seek to connect understandings of giftedness with understandings of disability, neither of which are universally defined nor accepted in the field (Ronksley-Pavia, 2015). The term twice-exceptionality recognises that students may have combinations of disabilities (e.g., autism spectrum disorders, and dyslexia) and giftedness (e.g., intellectual and creative); they may also have impairments, relative weaknesses and strengths (Foley-Nicpon, Assouline\& Colangelo, 2013; Ronksley-Pavia, 2015). As such, twice-exceptional students may have unique combinations of characteristics which can make them difficult to identify.

Twice-exceptionality is more pervasive than a simple connection between the definitions of giftedness and disability, particularly as many twice-exceptional students have multiple comorbid disabilities (Ronksley-Pavia, 2015; Ronksley-Pavia et al., 2019). To further 
complicate research and discourse on twiceexceptionality, multiple derivatives of twiceexceptionality are conflated, or sit within twiceexceptionality - for example, gifted with learning disability (GLD), double exceptionality, and dual exceptionality. All of these terms are frequently used interchangeably and in differing ways across the literature. This may be a source of confusion when attempts are made to review the literature or make comparisons across studies.

\section{International Origins of the Term Twice- Exceptional}

Internationally, particularly in North America, the identification and education of students who are twice-exceptional has become part of the educational vernacular over the last 20 years. Yet, the term twice-exceptionality is relatively new in Australia with knowledge and understanding among educators reflecting this novelty. Nevertheless, there has been close to 70 years of research on the topic. Hollingworth's (1923) work is possibly the earliest to describe students in special populations with outstanding characteristics (Baldwin, Baum, Pereles, \& Hughes, 2015; gifted and disability). In this work, Hollingworth discusses examples, such as children who demonstrated "discrepancy between two mental functions: (i) mental age...(Stanford-Binet), and (2) spelling ability" (p. 12). She proposed that these students "appeared to be characterized by special discrepancy" (p. 14) between high performance as demonstrated on the Stanford-Binet, and their "special disability in spelling" (p.14).

Nonetheless, it was not until over 50 years later that the duality of the concurrence of giftedness and disability was formally recognised. A national conference on "handicapped gifted and talented children" (Yewchuk \& Lupart, 1993, p. 709) held in 1976, resulted in the term gifted handicapped being included in the 1977 ERIC index (Yewchuk \& Lupart, 1993). In that same year, Maker (1977) introduced the concept that a child could be both gifted and have one or more disabilities in her seminal book Providing programs for the gifted handicapped.

Similarly, Whitmore and Maker (1985) provided commentary of the "new field of education for gifted handicapped students...emerging as a result of the intersection of special education for handicapped and for gifted students" (p. 5), without yet using the term twice-exceptionality. Rosner (1985) moved closer to conceptualising the term when referring to the enigma of children who are "both gifted and learning disabled" (p. 55) and "special-twice youngsters" (p. 58). Similarly, Silverman (1989) used the phrase "two exceptionalities" (p. 37) when discussing that "giftedness can be coupled with learning disabilities...[as] dual exceptionality" (p. 37).

Pfeiffer (2012) has noted that Gallagher is often credited with the first use of the term twiceexceptionality around 1988, although there is limited evidence to support this. Indeed, the first definite use of the term remains contentious. Interestingly, Pfeiffer (2012) credits the first actual use to Yewchuk and Lupart (1993), even though these authors use the term "duality" to refer to what we now understand as twice-exceptionality - "gifted handicapped those individuals of exceptional ability or potential who can achieve high performance, despite handicaps, such as hearing, visual...emotional disturbance, or learning disabilities" (p. 710). There is little evidence of actual use of the term twice-exceptionality in their work. It is likely that the first reference to twice-exceptionality for describing this population occurred much later than the 1990s, possibly in the year 2000, when Baldwin et al. (2015) described its initial appearance in American national organisations, and in federal and state policies.

\section{Overview of Twice-Exceptionality in Australia}

In Australia, the history of the term twiceexceptionality is even more indistinct than in North America. Nevertheless, it appears that an understanding of the coexistence of giftedness and disabilities had gained some recognition in Australia prior to the year 2000. For example, in 1984, the Commonwealth Schools Commission supported a national conference on the education of special populations of gifted and talented children which was inclusive of disabled children (Braggett, 1985a).

Braggett (1985b), in his report for the Commonwealth Schools Commission on the Education of Gifted and Talented Children from Populations with Special Needs, was the first to indicate that gifted children could exist in diverse populations, including children with disabilities:

The term disadvantaged group... is used by Australian educationalists to include Aborigines [sic], children from non-English speaking backgrounds, children with disabilities, economically deprived children, 
isolated children and girls,...there are proportionately as many gifted children among these groups as there are in the wider population (p. 1543).

Furthermore, in 1988, the Senate Select Committee on the Education of Gifted and Talented Children (Commonwealth of Australia) identified groups of gifted students who were at particular risk for non-identification, and included "children who were gifted but with a learning disability", "gifted students with physical disabilities - for example visually impaired or hearing impaired gifted students" (Gross, 2004, p. 4).

Initial references to the notion that children with disabilities could be gifted also appeared in Braggett (1985a) where mention was made of a Queensland initiative which accepted students who were identified as having an "above average ability, and in the gifted range with the program specifically open to migrants, aborigines [sic], disadvantaged, disabled and handicapped students" (p. 36). However, there appears to be limited use of the actual term twiceexceptionality prior to Wormald in 2009. Even in 2009, Wormald used the term to refer exclusively to gifted children with learning disabilities, rather than the full spectrum of disabilities that the term is now recognised as encompassing (Ronksley-Pavia, 2015a).

Frequently, Australian published studies have discussed anecdotal evidence and reviewed literature relating to twice-exceptionality. Many of these studies have made reference to gifted students with learning disabilities (GLD) (Chivers, 2012; Tuckerman, 2005), rather than twice-exceptionality as a whole. This may have the effect of leading to misunderstandings in the Australian education context of the meaning of the term, and some confusion over where GLD fits into this construct. The frequent interchangeable use of the terms GLD, twiceexceptionality, and dual exceptionality complicate the issue (Norris \& Dixon, 2011; Tuckerman, 2005; Turner, 2003; Wormald \& Vialle, 2011). This, in turn, may impact research exploring prevalence rates due to inconsistencies in the way in which the term twice-

exceptionality is defined and applied.

The use of the term LDs (as in GLD), implies that the fundamental appearance and demonstration of these student's disabilities solely affects their classroom learning, and that the rest of their physical and cognitive development proceeds smoothly and 'normally' (Melillo \& Leisman, 2004). The assumption here is that LDs only affect their learning. The reality is more comparable to their everyday experience being socio-culturally constructed in relation to their disabilities and their giftedness, and the interplay and variability of these (Ronksley-Pavia et al., 2019; Ronksley-Pavia \& Townend, 2017).

Estimating prevalence rates of students with twice-exceptionality, both within Australia and internationally, is hindered by these recurrent discrepancies in defining giftedness, disability and subsequently, twice-exceptionality. As noted by Ronksley-Pavia (2015), when endeavouring to understand twice-exceptionality, the field is obscured by clouded definitions of both giftedness and disability. The term twiceexceptionality is often over-simplified to GLD, even though not all twice-exceptional learners have a learning disability. Similarly, using the term gifted with a learning difficulty removes the legislative cover afforded to individuals with disability under legislation such as the Disability Discrimination Act (Commonwealth of Australia, 1992). Moreover, the term learning difficulty diminishes the impact disabilities can have on a student's access to, inclusion in, and outcomes from, education.

\section{Presentation of Twice-Exceptionality in the Australian Context}

Over the last five years, educators' understanding, and recognition of twiceexceptional students has improved incrementally, yet twice-exceptional students are largely unrecognised in Australian schools and education policy. There is little in place for identifying these students, and consequently they are seldom catered for (Wormald, 2009, 2011a), leading to potential for underachievement and disengagement. There remains widespread lack of knowledge, or recognition by educators that these students exist, and subsequently limited awareness of how to cater for their specific needs (Wormald, 2011a, 2011b). Common thought appears to be that a student identified as gifted is globally so, and that disabilities and giftedness are on a spectrum of disabled at the lower end and gifted at the upper end, when in actuality there is no correlation between being gifted and having disabilities (Silverman, 2003, 2005; Tannenbaum \& Baldwin, 1983). Furthermore, the conflation of disabilities as a lack of ability further complicates understanding and recognition of twice-exceptional learners.

Unfortunately, there is a considerable gap in empirical research in the area of twiceexceptionality in Australia, particularly with respect to the prevalence of these students in schools. We recognise that governments expect 
statistics when developing education policy. It is therefore, imperative on the field, as far as practicable, to quantify the numbers of twiceexceptional learners in Australia. By doing so, it is envisaged that support will be garnered for this underacknowledged and consequently underserved population of learners who, just like any other special needs group, have specific educational requirements in order for them to be able to achieve educational outcomes commensurate with their potential.

\section{Prevalence Estimates from the Literature}

Notwithstanding the aforementioned issues in relation to defining twice-exceptionality, there are some antecedents in the literature regarding estimating the prevalence of twice-exceptional students. Internationally, various estimates have been proposed (see Table 1).

Whitmore and Maker (1985) appear to have been the first to consider this prevalence quandary and conservatively estimated "that $2 \%$ of the handicapped children could be classified as mentally gifted" (p. 11-12). They qualified this estimate by stating that there were neither accurate nor reliable statistics for the number of students with both giftedness and specific disabilities. In many ways, the $2 \%$ estimate appears quite low: this could be for a number of reasons, the main being that IQ was the likely basis for identification of giftedness, rather than today's more holistic identification methods. Furthermore, the classification was termed "mentally gifted", which does not equate to some models of giftedness, such as Gagné's model that also recognises other domains of giftedness (e.g., sensorimotor, creative).

In comparison, Waldron and Sapphire (1992) suggested IQ could be depressed by LD, that is if the LD is actually identified during schooling. Ferri, Gregg, and Heggoy, (1997) identified that $41 \%$ of students with both gifts and LD (i.e., one kind of twice-exceptionality), remained undiagnosed until their college years, suggesting LD and giftedness may be masked at school. This finding also has implications for estimating prevalence estimates of twice-exceptionality among school students given that both giftedness and LD, and/or other disabilities, may not be identified until later in life, if at all. Of note, Silverman (1989) recommended in selection processes for special provisions for gifted learners that students with LD should have at least 10 points added to their IQ score due to the possible impact of LDs on depressing IQ scores.

Likewise, Maddocks (2018) cautions about the methods used to identify twice-exceptional students, particularly a reliance on the discrepancy model. This model, which is the dominant model for identifying learning disabilities, relies on a discrepancy between ability and achievement, suggesting that this would overidentify students with specific learning disabilities. However, using cognitive assessments (e.g., WISC-V) may add value to a comprehensive evaluation, with some suggesting that a large discrepancy between subtest scores may provide some evidence to support the identification of twice-exceptionality (Neihart, 2008). Although the methods of identification of twice-exceptionality remain contentious, FoleyNicpon, Allmon, Sieck, and Stinson (2011) suggest it is critical that a comprehensive individualised evaluation is needed to understand a student's relative strengths and weaknesses, such as an individualised evaluation which "employs an intra-individual, rather than an inter-individual approach toward ability and achievement analysis" (p. 7).

There are many cautions about prevalence estimates from the literature. In particular, percentages and prevalence estimate data need to be viewed with caution as some of these data are not always presented clearly. For example, a $36 \%$ prevalence rate (Baum \& Owen, 1988) potentially indicates $36 \%$ of all students are twice-exceptional. However, the reference group for this percentage is actually students with learning disabilities who show "some evidence of potential for gifted behaviour" (Baum \& Owen, 1988, p. 324), although they may not necessarily be identified as gifted.

Other prevalence estimates of twiceexceptionality range from $2 \%$ to $20 \%$ (Cortiella \& Horowitz, 2014; Pfeiffer, 2001) of the gifted population. In comparison, estimates for the prevalence of LDs among gifted students (one form of twice-exceptionality) range from $2 \%$ to 36\% (Baum \& Owen, 1988). One consistent thread among these authors is their constant caution that their estimates are very conservative (Foley-Nicpon et al., 2013). Unfortunately, empirical data regarding the actual incidence of twice-exceptional children, however, are virtually non-existent (Nielsen, 2002).

One important consideration in the examination of prevalence rates is the need to ascertain whether the rates cited across the literature are 
Table 1

Summary of Prevalence Estimates from the Literature

\begin{tabular}{|c|c|c|c|}
\hline Author(s) & Prevalence Estimate & Definition Used & Country \\
\hline Whitmore (1981) & $2 \%$ to $5 \%$ of gifted students & $\begin{array}{l}\text { Gifted and talented } \\
\text { students with learning } \\
\text { disability }\end{array}$ & USA \\
\hline Mauser (1981) & $2.3 \%$ students with LDs also gifted & $\begin{array}{l}\text { Gifted students with } \\
\text { LDs }\end{array}$ & USA \\
\hline Baum \& Owen (1988) & $\begin{array}{l}\text { 36\% LD with gifted behaviour } \\
\text { (twice-exceptional) }\end{array}$ & $\begin{array}{l}\text { LD with gifted } \\
\text { behaviour }\end{array}$ & USA \\
\hline $\begin{array}{l}\text { Whitmore \& Maker } \\
\text { (1985) }\end{array}$ & $\begin{array}{l}5 \% \text { of population with disabilities } \\
\text { also gifted }\end{array}$ & $\begin{array}{l}\text { Students with } \\
\text { disabilities who also } \\
\text { gifted }\end{array}$ & USA \\
\hline Silverman (1989) & $1.4 \%$ of gifted students also had LD & $\begin{array}{l}\text { Gifted students who } \\
\text { also have LD }\end{array}$ & USA \\
\hline Pfeiffer (2001) & Gifted $5 \%$ to $20 \%$ of population & Gifted & \\
\hline Munro (2002) & $\begin{array}{l}30 \% \text { of gifted students exhibit a } \\
\text { learning disability }\end{array}$ & Gifted with LD & Australia \\
\hline Nielsen (2002) & $\begin{array}{l}\text { 3.5\% identified as gifted learning } \\
\text { disabled from US federally funded } \\
\text { Twice-Exceptional Child Project }\end{array}$ & $\begin{array}{l}\text { Gifted learning } \\
\text { disabled }\end{array}$ & USA \\
\hline $\begin{array}{l}\text { National Education } \\
\text { Association (2006) }\end{array}$ & $\begin{array}{l}\text { Based on United States Department } \\
\text { of Education data from } 2002: 6 \% \\
\text { school population are gifted; } 6 \% \text { of } \\
\text { these students (aged } 6-21 \text { years) } \\
\text { are twice-exceptional, that is they } \\
\text { are served by the US Individuals } \\
\text { with Disabilities Education Act } \\
\text { (IDEA) }\end{array}$ & $\begin{array}{l}\text { Twice-exceptional } \\
\text { those gifted who are } \\
\text { also served by IDEA }\end{array}$ & USA \\
\hline Rogers (2010) & $\begin{array}{l}14 \% \text { of gifted students demonstrate } \\
\text { some form of twice-exceptionality }\end{array}$ & $\begin{array}{l}\text { Some form of twice- } \\
\text { exceptionality among } \\
\text { gifted student }\end{array}$ & USA \\
\hline $\begin{array}{l}\text { Foley-Nicpon et al. } \\
\text { (2013) }\end{array}$ & $\begin{array}{l}1 \% \text { to } 11 \% \text { or higher; results from } \\
\text { survey of stakeholders (e.g., } \\
\text { parents, teachers) }\end{array}$ & $\begin{array}{l}\text { Percentage of gifted } \\
\text { students that } \\
\text { stakeholders believed } \\
\text { were also twice- } \\
\text { exceptional }\end{array}$ & USA \\
\hline $\begin{array}{l}\text { Cortiella \& Horowitz } \\
(2014)\end{array}$ & $\begin{array}{l}5 \% \text { to } 20 \% \text { of the gifted population } \\
\text { are } 2 \mathrm{e}\end{array}$ & $\begin{array}{l}\text { Specific learning } \\
\text { disability (SLD) of the } \\
\text { gifted population }\end{array}$ & USA \\
\hline $\begin{array}{l}\text { Barnard-Brak et al., } \\
(2015)\end{array}$ & $\begin{array}{l}7-9 \% \text { and } 9.1 \% \text { of students with } \\
\text { disabilities also gifted }\end{array}$ & $\begin{array}{l}\text { Students with } \\
\text { disabilities who are } \\
\text { also gifted }\end{array}$ & USA \\
\hline $\begin{array}{l}\text { Bell, Taylor, } \\
\text { McCallum, Coles \& } \\
\text { Hays (2015) }\end{array}$ & $\begin{array}{l}16 \% \text { maths SLD } \\
24.5 \% \text { reading SLD }\end{array}$ & $\begin{array}{l}\text { Gifted with specific } \\
\text { learning disability }\end{array}$ & \\
\hline Ivicevic (2017) & $\begin{array}{l}1.6 \% \text { of students who } \\
\text { accepted a place in the Western } \\
\text { Australia Gifted \& Talented } \\
\text { Academic programs }\end{array}$ & $\begin{array}{l}\text { Twice-exceptional } \\
\text { students who } \\
\text { accepted a place in a } \\
\text { gifted program in } \\
\text { Western Australia }\end{array}$ & Australia \\
\hline
\end{tabular}

a percentage of all students, a percentage of gifted students, or a percentage of twiceexceptional students, or even a percentage of a subpopulation of twice-exceptional students (e.g., those with LDs/SLDs). For example Silverman (1989) found that $1.4 \%$ of gifted students also had an LD. This represents a contrast with Barnard-Brak, Johnsen, Pond Hannig, and Wei 's (2015) estimate that 9\% of students with disabilities "might be considered academically advanced or potentially gifted" ( $p$. 77). 
In essence, most calculations of prevalence estimates appear to either begin with numbers of students with disabilities (e.g., LDs/SLDs), and then estimate the number of those who are also gifted, or conversely begin with the numbers of gifted students and then attempt to estimate the number of those with co-occurring disabilities While this review of the field of potential prevalence rates for twice-exceptionality is fraught with complications, these percentages provide us with some workable starting points. We now know that the older the estimates the less likely they are to have considered a holistic definition of giftedness as widely accepted today. We can also begin to work through what is recognised to estimate what is not yet known.

\section{Prevalence Estimates for Australia}

To date there are limited comprehensive prevalence estimates or studies relating specifically to the numbers of twice-exceptional students in Australia (or across the world). This may be the result of fuzzy definitions and problems associated with identification. However, working from the aforementioned estimates from the literature, it may be possible to approximate the numbers of twiceexceptional students in Australia.

In 2014, Ronksley-Pavia estimated that of the 4,115,334 Australian children, 28,835 children may be identified as twice-exceptional. This was drawn from 2009 Australian Bureau of Statistics Survey of Disability, Aging and Carers (SDAC) (Australian Bureau of Statistics [ABS], 2011) data. However, this approximation contained a number of highly limiting caveats, particularly around the age of children (i.e., 0-14 year old children, rather than school-age children aged 518 years).

The SDAC considered children aged 0-14 years with a disability, defined as "any limitation, restriction or impairment which restricts everyday activities and has lasted or is likely to last for at least six months" (ABS, 2011, p. 3). Such disabilities could include any sensory, speech, intellectual, physical disability, mental or behavioural disorders (ABS, 2011). Of the $4,115,334$ children in Australia in 2009, the survey identified 288,348 (7\%) with a disability. From the SDAC data, Ronksley-Pavia (2014), extrapolated that $10 \%$ of these children could be regarded as being gifted using Gagné's (2009) model. Such an estimation may be considered conservative as Gagné has previously suggested that "...at least $10-15 \%$, at least three or four students in a mixed ability class of 30 could be gifted ... . And of course there is often overlap between the domains" (Gross, 2004, p. 4). Therefore, considering a 10\% prevalence of giftedness in the wider population as being the lower estimate (Gagné, 2009), of the 4,115,334 children identified has having a disability (ABS, 2011), a conservative estimate of the prevalence of those potentially gifted in this population (and therefore twice exceptional) would be 411,533 children.

Prevalence estimates from the literature up to 2009 have speculated that $7 \%$ to $9 \%$ of gifted students could be considered twice-exceptional. In Australia, in 2009, this equated to between 28,807 and 37,038 children potentially being twice-exceptional. Unfortunately, these estimates carried a number of limitations that made them highly unreliable: (a) the source survey likely excluded those with specific learning disabilities, who did not have a comorbid disability as defined by the survey, (b) the survey did not include children aged 15 to 18 who may also have disability, (c) initial disability prevalence from the ABS survey was of children aged 0-14 (rather than school aged students), (d) children with specific learning disabilities were likely to have been excluded, and (e) statistical issues were confounded when estimating the number of twice-exceptional students from the hypothetical gifted population. Consequently, available data at the time did not enable reliable prevalence estimates to be calculated of the number of twice-exceptional students in Australian schools.

Given the limitations of the available data in 2014, the prevalence estimate of twiceexceptionality in Australian school students was seen at best as being unreliable due to the shortcomings in the quality of data available at the time. Therefore, we delayed pursuing prevalence estimates until more reliable data became available from the implementation of the NCCD (2020a), and potentially more reliable data on Australian school students receiving adjustments for disability.

The NCCD is a combined scheme of all Australian governments and government and nongovernment education authorities. National data is collected annually to identify the number of school students with disability and the level of reasonable adjustment provided for them. This national data collection was progressively implemented in Australian schools from 20132015. Since 2015, all schools have participated annually in the national data collection. 
The NCCD relies on information from schools across Australia to identify students who receive educational adjustments as a result of their disability. An educational adjustment is defined by the NCCD as any "actions taken to enable a student with disability to access and participate in education on the same basis as other students. Adjustments reflect the assessed individual needs of the student. They can be made at the whole-school level, in the classroom and at an individual student level" (NCCD, 2020b, para. 2). The information collected from schools with this survey is based on the broad definition of disability used in the Disability Discrimination Act (Commonwealth of Australia, 1992) and the Disability Standards for Education

(Commonwealth of Australia, 2005), along with the following information (NCCD, 2020b):

1. The level of adjustment that students with disability are being provided to enable them to participate in education on the same basis as other students:
- Support within quality differentiated teaching practice
- Supplementary
- Substantial
- Extensive

2. The broad category of disability under which each student best fits:
- Physical
- Cognitive
- Sensory
- Social-emotional

\section{Prevalence of Twice-Exceptionality in Australian Schools}

The most recently available statistics on the number of school students in Australian schools, and the number of students with disability, comes from 2019. Australian government data from 2019 indicates a total of $3,948,811$ students are enrolled in Australian schools (ACARA, 2019b). Applying Gagné's 10\% cut off for giftedness would potentially mean that the number of students who are gifted in Australia is 394,881. According to NCCD data (ACARA, 2019a), the number of students in schools in 2019 receiving educational adjustments for disability was 786,678 students (19.9\%). Applying Gagne's $10 \%$ to this population, it is feasible to estimate that the possible number of twiceexceptional students in 2019 receiving educational adjustments at school for their disabilities, was 78,668 students (or $2 \%$ of the total number of students in Australian schools; See Figure 1). Table 2 provides further details.
It is noted that these estimates are likely to be extremely conservative, as the prevalence estimates only reflect those students with identified disabilities receiving educational adjustments at schools. As we know from previous research, twice-exceptional students can remain unidentified at school, due to the masking effects of their disabilities (McCoach, Kehle, Bray \& Siegle, 2001), or compensatory strategies, or because they do not receive educational adjustments at school for their disability. This conceivably leads to an underestimation of this population when using disability statistics alone.

A less conservative estimate of the prevalence of twice-exceptional students in Australia could use the rate of $20 \%$ of the gifted student population proposed by Pfeiffer (2001) and Cortiella and Horowitz (2014). This would mean that 157,336 Australian school students may well be twiceexceptional. If the highest rate of 36\% (Baum \& Owen, 1988), relating specifically to gifted students with LDs, is applied to the NCCD data on the number of students with disability (receiving educational adjustments), the prevalence estimate of twice-exceptional students in Australia would rise to 283,204.

All of these prevalence estimates could be placed on a continuum, with the lower end reflecting the conservative $10 \%$ rate among students with disability receiving educational adjustments, and the upper end reflecting the highest rate of $36 \%$ of students with disability receiving educational adjustments (according to the NCCD data). This equates to a prevalence estimate of twice-exceptional students in Australian schools ranging from $2 \%$ to $7 \%$ (see Figure 2). It is important to recognise that these estimates are drawn from the available NCCD data for students with disability who receive adjustments in school. These data do not reflect students with disability who do not receive educational adjustments. As such these prevalence estimates are conservative and likely lower than the actual population of twiceexceptional students in schools.

One of the interesting findings here is that there appears to be a higher proportion of gifted students $(20 \%$ to $36 \%)$ in the population of students with disability than in the population of all students who are gifted (10\% or $15 \%)$. Of course, this is dependent on which population the twice-exceptional prevalence estimate is being drawn from; students with disability or students who are gifted. Nonetheless, regardless of how these prevalence estimate statistics are viewed, there appears to be a considerable 
Table 2

Data Presentation of Prevalence Estimates for Twice-Exceptionality in Australian Schools

\begin{tabular}{|c|c|c|}
\hline Category & Number of Students & $\begin{array}{l}\text { Percentage of Total Number of } \\
\text { School Students in } 2019\end{array}$ \\
\hline Number of students in Australian schools & $3,948,811$ & $100 \%$ \\
\hline $\begin{array}{l}\text { Number of gifted students (applying } \\
\text { Gagné's 10\%) }\end{array}$ & 394,881 & $10 \%$ \\
\hline $\begin{array}{l}\text { Number of gifted students (applying } \\
\text { Gagné's } 15 \% \text { ) }\end{array}$ & 592,322 & $15 \%$ \\
\hline $\begin{array}{l}\text { Total number of students with disability } \\
\text { receiving educational adjustments } \\
\text { (NCCD, 2019; ACARA, 2019) }\end{array}$ & 786,678 & $19.9 \%$ \\
\hline $\begin{array}{l}\text { Number of students receiving } \\
\text { educational adjustments for disability } \\
\text { who could also be gifted (applying } \\
\text { Gagné's } 10 \% \text { ) }\end{array}$ & 78,668 & $2 \%$ \\
\hline $\begin{array}{l}\text { Number of students receiving } \\
\text { educational adjustments for disability } \\
\text { who could also be gifted (applying } \\
\text { Gagné's } 15 \% \text { ) }\end{array}$ & 118,002 & $3 \%$ \\
\hline $\begin{array}{l}\text { Number of students who could be twice- } \\
\text { exceptional applying } 20 \% \text { (of students } \\
\text { with disability) from the literature }\end{array}$ & 157,336 & $\begin{array}{c}4 \% \\
\text { (20\% of students with disability } \\
\text { receiving educational } \\
\text { adjustments) }\end{array}$ \\
\hline $\begin{array}{l}\text { Number of students who could be twice- } \\
\text { exceptional applying } 36 \% \text { (GLD) from the } \\
\text { literature }\end{array}$ & 283,204 & $\begin{array}{l}7 \% \\
\text { (36\% of students with disability } \\
\text { receiving educational } \\
\text { adjustments) }\end{array}$ \\
\hline $\begin{array}{l}\text { Total range for prevalence estimates } \\
\text { of twice-exceptionality in Australia }\end{array}$ & 78,668 to 283,204 & $2 \%$ to $7 \%$ \\
\hline
\end{tabular}

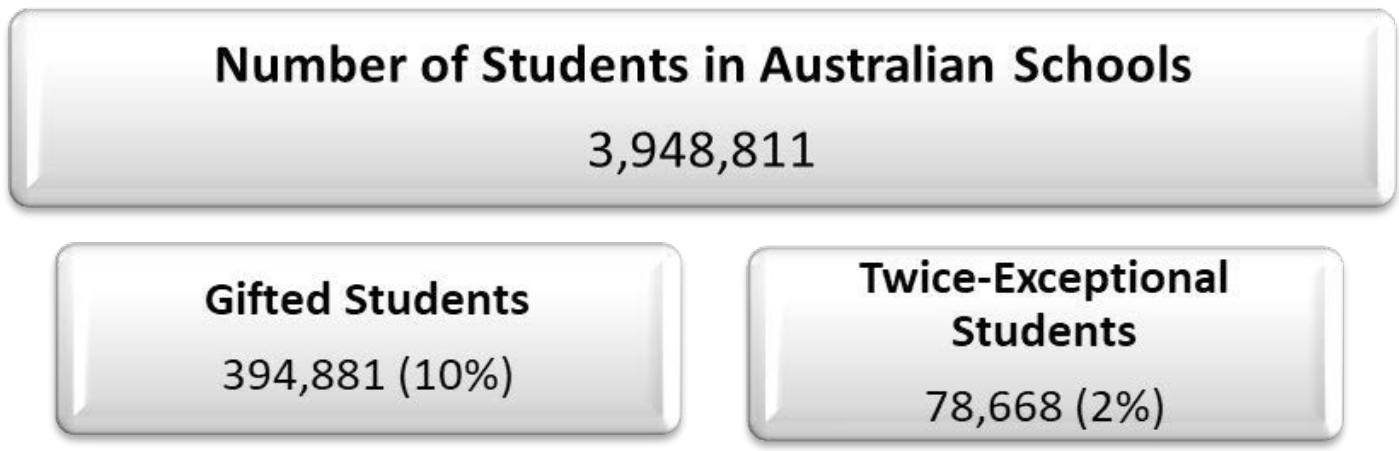

Figure 1. Summary of prevalence estimates for Australian students. 


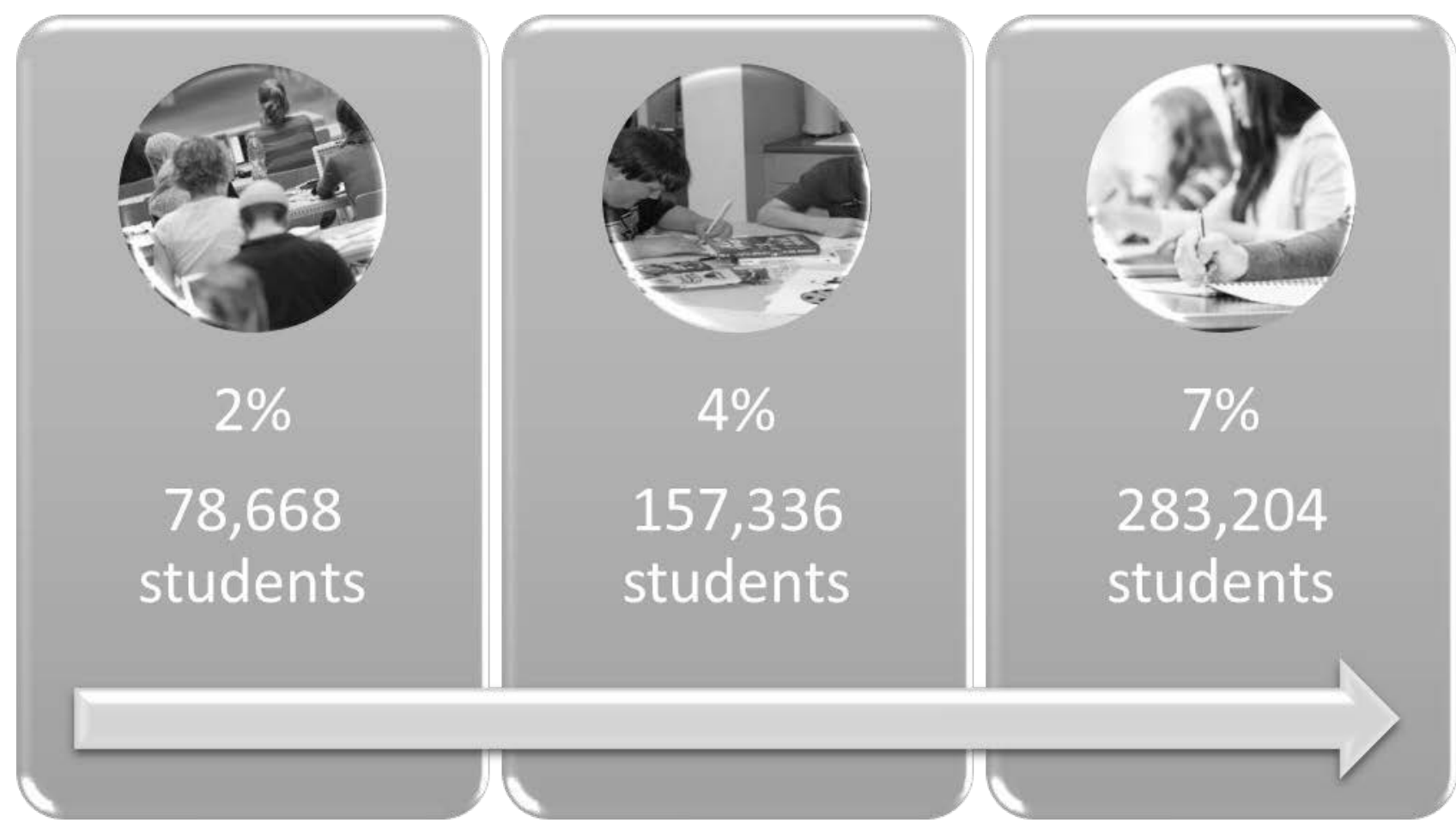

Figure 2. A continuum of twice-exceptional prevalence for Australian school students.

number of twice-exceptional students in Australian schools, which may be larger than previously estimated. This situation warrants specific attention, development and implementation of policy, and funding decisions, to enable educators to understand and support this important group of students.

Until the goals of supporting both gifted and twice-exceptional students in Australian schools are achieved, the goals around achieving equity in education will remain a pipedream. Australian state and territory education ministers vision "for a world class education system that encourages and supports every student to be the very best they can be, no matter where they live or what kind of learning challenges they may face" (Education Services Australia, 2019, p. 2), will also remain unfulfilled.

\section{Limitations}

Due to the issues associated with defining and identifying twice-exceptional students, there are a number of limitations in any investigation of prevalence estimates. First, identification criteria for both giftedness and disability may be problematic because the models used to categorise and define both exceptionalities are not universally accepted.
Second, there are inherent problems with using separate measures (i.e., disability and giftedness), and joining these to calculate prevalence estimates of twice-exceptionality. Twice-exceptionality is more complex and nuanced than just joining the two exceptionalities together; this could lead to oversimplification when looking at separate categories of disability and then giftedness.

Third, any estimations of the prevalence of twice-exceptional students that make use of official data, such as the NCCD disability statistics may not be accurate, as such data only recognise students who are currently receiving educational adjustments in the classroom for their disability, rather than all students with disabilities. These data also do not include students who do not yet have a formal disability diagnosis.

Finally, there are likely to be some limitations relating to the reliability of any data on the number of gifted students in Australia due to the lack of formal (or mandated) data collection.

\section{Conclusion}

The field of twice-exceptional research in Australia has been growing since the year 2000; 
however, still little is known about the prevalence rates of these students in Australian schools. This article set out to ascertain a reliable estimate for the number of students who may be twice-exceptional, based on currently available data, and on North American research. Drawing on these data, it is estimated that the number of twice exceptional students in Australia may range from 78,668 to 283,204 . This equates to a range from a conservative $2 \%$ to a progressive $7 \%$ of the total number of Australian students. It is hoped that future research will investigate a more precise prevalence of Australian twice-exceptional students, using more direct methods, to garner funding and policy support for this neglected population of Australian students.

\section{References}

ACARA. (2019a). School students with disability. https://www.acara.edu.au/reporting/nationa l-report-on-schooling-in-australia/nationalreport-on-schooling-in-australia-dataportal/school-students-with-disability

ACARA. (2019b). Student numbers.

https://www.acara.edu.au/reporting/nationa l-report-on-schooling-in-australia/nationalreport-on-schooling-in-australia-dataportal/student-numbers

Australian Bureau of Statistics (ABS). (2011). Disability, Ageing and Carers, Australia: Summary of Findings 2009, 4430.0. Commonwealth of Australia.

Baldwin, L., Baum, S., Pereles, D., \& Hughes, C. (2015). Twice-exceptional learners: The journey toward a shared vision. Gifted Child Today, 38(4), 206-214. https: / /doi.org/10.1177/1076217515597277

Barnard-Brak, L., Johnsen, S. K., Pond Hannig, A. , \& Wei, T. (2015). The incidence of potentially gifted students within a special education population. Roeper Review, 37(2), 74-83.

https: / /doi.org/10.1080/02783193.2015.1008 661

Baum, S., \& Owen, S. V. (1988). High ability/learning disabled students: How are they different? Gifted Child Quarterly, 32(3), 321-326.

https: / /doi.org/10.1177/00169862880320030 5

Braggett, E. J. (1985a). Education of gifted and talented children: Australian provision.Commonwealth Schools Commission.

Braggett, E. J. (1985b). Education of gifted and talented children from populations with special needs: Discussion documents.
Commonwealth Schools Commission.

Chivers, S. (2012). Twice-exceptionality in the classroom. Journal of Student Engagement: Education Matters, 2(1), 26-29.

Commonwealth of Australia. (1988). The education of gifted and talented children: Report by the Senate Select Committee on the education of gifted and talented children. Australian Government Publishing Services.

Commonwealth of Australia. (1992). Disability Discrimination Act. Canberra: Office of Legislative Drafting and Publishing. Retrieved from

http://www.austlii.edu.au/au/legis/cth/cons ol_act/dda1992264/.

Commonwealth of Australia. (2005). Disability Standards for Education 2005 with guidance notes. Canberra, ACT: Commonwealth of Australia. Retrieved from http: / /www.deewr.gov.au/Schooling/Progra ms/Documents/Disability_Standards_for_Educ ation_2005_pdf.pdf.

Cortiella, C., \& Horowitz, S. H. (2014). The state of learning disabilities: Facts, trends and emerging issues (Third). National Center for Learning Disabilities.

Education Services Australia. (2019). Alice Springs (Mparntwe) Education Declaration. https: / /docs.education.gov.au/system/files/ doc/other/final_-_alice_springs_declaration__17_february_2020_security_removed.pdf

Ferri, B. A., Gregg, N., \& Heggoy, S. J. (1997). Profiles of college students demonstrating learning disabilities with and without giftedness. Journal of Learning Disabilities, 30(5), 552-559. https: / /doi.org/10.1177/00222194970300051 1

Foley-Nicpon, M., Assouline, S. G., \& Colangelo, N. (2013). Twice-exceptional learners. Gifted Child Quarterly, 57(3), 169-180. https: //doi.org/10.1177/0016986213490021

Foley Nicpon, M., Allmon, A., Sieck, B., \& Stinson, R. D. (2011). Empirical investigation of twice-exceptionality: Where have we been and where are we going? Gifted Child Quarterly, 55(1), 3-17. https: / /doi.org/10.1177/0016986210382575

Gagné, F. (2009). Building gifts into talents: Detailed overview of the DMGT 2.0. In B. MacFarlane \& T. Stambaugh (Eds.), Leading change in gifted education: The festschrift of Dr. Joyce VanTassel-Baska. Prufrock Press.

Gagné, F. (2013). The DMGT: Changes within, beneath, and beyond. Talent Development \& Excellence, 5(1), 5-19.

Gross, M. U. M. (2004). Gifted and Talented Education Professional Development Package for Teachers: Module 1 Primary. 
https: / / docs.education.gov.au/system/files/ doc/pdf/gifted_talented_education_module1 _primary.pdf

Haines, M. A., Cornish, L., Bannister-Tyrrell, M. (2020). Might this student be twiceexceptional?: A preliminary assessment tool for primary-school teachers. Australasian Journal of Gifted Education, 29(1), 23-40. https://doi.org/ 10.21505/ajge.2020.0003

Hollingworth, L. (1923). Special talents and defects: Their significance for education. Cornell University Library.

Maddocks, D. L. S. (2018). The identification of students who are gifted and have a learning disability: A comparison of different diagnostic criteria. Gifted Child Quarterly, 62(2), 175-192. https://doi.org/10.1177/0016986217752096

Maker, J. (1977). Providing programs for the gifted handicapped. Council for Exceptional Children: Reston, VA

McCoach, D. B., Kehle, T. J., Bray, M. A., \& Siegle, D. (2001). Best practices in the identification of gifted students with learning disabilities. Psychology in the Schools, 38(5), 403-411. https://doi.org/10.1002/pits.1029

Melillo, R., \& Leisman, G. (2004). Neurobehavioral Disorders: An Evolutionary Perspective. Kluwer Academic Publishers: New York, NY.

Munro, J. (2002). Understanding \& identifying gifted learning disabled students. Australian Journal of Learning Disabilities, 7(2), 20-31. https: / /doi.org/10.1080/19404150209546698

Nationally Consistent Collection of Data on School Students with Disability. (2020a). Information Notice on Nationally Consistent Collection of Data - Students with Disability. www.legislation.gov.au/Current/F2018C00920

Nationally Consistent Collection of Data on School Students with Disability. (2020b). Step 1: Is there an adjustment? https: / /www.nccd.edu.au/wider-supportmaterials/step-1-thereadjustment?parent=/understandingnccd\&activity=/wider-supportmaterials/what-nccd-model-1\&step $=1$

Neihart, M. (2008). Identifying and providing services to twice-exceptional children. In S. I. Pfeiffer (Ed.), Handbook of giftedness in children: Psychoeducational theory, research, and best practice (pp. 115-137). Springer: New York, NY.

Nielsen, M. E. (2002). Gifted Students With Learning Disabilities: Recommendations for Identification and Programming, Exceptionality. Exceptionality, 10(2), 93-111. https: //doi.org/10.1207/ S15327035EX1002_4

Norris, N., \& Dixon, R. (2011). Twice exceptional - Gifted students with Aspergers syndrome. The Australasian Journal of Gifted Education, 20(2), 34-45.
Pfeiffer, S. I. (2001). Professional psychology and the gifted: Emerging practice opportunities. Professional Psychology, Research and Practice, 32(2), 175-180. https: / /doi.org/10.1037/0735-7028.32.2.175

Pfeiffer, S. I. (2012). Gifted Students with coexisting disabilities: The Twice exceptional. In S. I. Pfeiffer (Ed.), Serving the gifted: Evidence-based clinical and psychoeducational practice (pp. 119-136). Routledge.

Ronksley-Pavia, M. (2014). An empirical investigation of twice-exceptional research in Australia: Prevalence estimates for gifted children with disability. Australian Association for Research in Education. AARE-NZARE 2014 Speaking Back Through Research Conference. https: / /www.aare.edu.au/publicationsdatabase.php/8885/an-empiricalinvestigation-of-twice-exceptional-researchin-australia-prevalence-estimates-for-gifte

Ronksley-Pavia, M. (2015). A model of twiceexceptionality: Explaining and defining the apparent paradoxical combination of disability and giftedness in childhood. Journal for the Education of the Gifted, 38(3), 318340.

https: / /doi.org/10.1177/0162353215592499

Ronksley-Pavia, M., Grootenboer, P., \& Pendergast, D. (2019). Privileging the voices of twice-exceptional children: An Exploration of lived experiences and stigma narratives. Journal for the Education of the Gifted, 42(1), 4-34. https: / /doi.org/10.1177/0162353218816384

Ronksley-Pavia, M., \& Townend, G. (2017). Listening and responding to twice exceptional students: Voices from within. TalentEd, 29, 32-57.

Rosner, S. (1985). Guidelines for developing effective programs for gifted children with specific learning disabilities. Gifted Child Today, 8(3), 55-58. https: / / doi.org/10.1177/10762175850080033 6

Silverman, L. K. (1989). Invisible gifts, invisible handicaps. Roeper Review, 12(1), 37-42. https: / / doi.org/10.1080/02783198909553228

Silverman, L. K. (2003). Gifted children with learning disabilities. In N. Colangelo \& A. D. Davis (Eds.), Handbook of gifted education (3rd ed., pp. 533-543). Allyn \& Bacon: Boston, MA.

Silverman, Linda Kreger. (2005). The two-edged sword of compensation: How the gifted cope with learning disabilities.

http://citeseerx. ist.psu.edu/viewdoc/downlo ad?doi=10.1.1.511.5584\&rep=rep1\&type=pdf

Tannenbaum, A. J., \& Baldwin, L. J. (1983). A paradoxical combination. In L. H. Fox, L. Brody, \& D. Tobin (Eds.), Learningdisabled/gifted children: Identification and 
programming (pp. 11-36). University Park Press: Baltimore.

Townend, G., \& Pendergast, D. (2015). Student voice: What can we learn from twiceexceptional students about the teacher's role in enhancing or inhibiting academic selfconcept. Australasian Journal of Gifted Education, 24(1), 37-51. https://doi.org/10.21505/ajge.2015.0006

Tuckerman, S. (2005). Gifted, and learning disabled. TalentEd, 1 \& 2(2005-2006), 45-53.

Turner, C. (2003). Visual spatial children: Learning disabled, learning disavantaged or learning differently? TalentEd, 21(1), 10-20.

Waldron, K. A., \& Saphire, D. G. (1992). Perceptual and academic patterns of learning-disabled/gifted students. Perceptual \& Motor Skills, 74(2), 599-609. https: //doi.org/10.2466/pms.1992.74.2.599

Whitmore, J. R. (1981). Gifted children with handicapping conditions: A new frontier. Exceptional Children, 48(2), 106-113. https: //doi.org/10.1177/00144029810480020 3

Whitmore, J. R., \& Maker, J. C. (1985). Intellectual giftedness in disabled persons. PRO-ED: Austin, TX.

Wormald, C. (2009). An enigma: Barriers to identification of gifted students with a learning disability [University of Wollongong, Wollongong, New South Wales, Australia]. http: / / www.australiangiftedsupport.com/gpa ge13.html

Wormald, C. (2011a). Teachers' knowledge of gifted learning disabled students in NSW. In C. Wormald \& N. Vialle (Eds.), Dual Exceptionality (pp. 87-94). Australian Association for the Education of the Gifted and Talented: Sydney: NSW.

Wormald, C. (2011b). What knowledge exists in NSW schools of students with learning difficulties who are also academically gifted? Australasian Journal of Gifted Education, 20(9), 5-9.

Wormald, C., \& Vialle, W. (2011). Dual Exceptionality. Australian Association for the Education of the Gifted and Talented Ltd (AAEGT). http: / /www.aaegt.net.au/DEEWR Books/DE Final Compile.pdf

Yewchuk, C., \& Lupart, J. L. (1993). Gifted handicapped: A desultory duality. In K. A. Heller, F. J. Monks, \& A. H. Passow (Eds.), International handbook of research and development of giftedness and talent (pp. 709-725). Pergamon Press: London. 


\section{Contact Details}

Michelle Ronksley-Pavia

Email: m.ronksley-pavia@griffith.edu.au

\section{Biographical Notes}

Dr Michelle Ronksley-Pavia, FHEA, is a lecturer in Professional Experience and Special \& Inclusive Education in the School of Education and Professional Studies, Griffith University, Australia. She is an international leading researcher and expert in the field of gifted education and twice exceptionality. Michelle is a member of the World Council for Gifted and Talented Children (WCGTC), the WCGTC Teacher-Education-Committee, SPELD Victoria Research Committee, and AAEGT member. Her expertise as a leader in the field of twiceexceptional research and advocacy has recently been recognised by the Bridges 2e Center for Research and Professional Development (US). 